\title{
PARAMUZOA (NYCTIBORINAE), A NEW COCKROACH GENUS PREVIOUSLY CONFUSED WITH PARASPHAERIA (EPILAMPRINAE)*
}

\author{
By Louis M. Roth \\ Pioneering Research Laboratory \\ U.S. Army Natick Laboratories \\ Natick, Massachusetts or 760
}

Kirby (1904, p. 194) placed Parasphaeria Brunner in the Perisphaeriinae, probably because Brunner (1865) stated that the genus was near Perisphaeria Burm. Princis (1964) placed the genus in the Perisphaeriidae. While studying the male genitalia of genera which Princis assigned to the Perisphaeriidae, I found the phallomeres of Parasphaeria ovata (Blanchard) (type of genus, Princis, I964, p. 240) to be more typical of the genitalia of genera which belong to the Epilamprinae and that Parasphaeria linearis (Serville) is not a member of ovoviviparous Parasphaeria, but is an oviparous species.

All ovoviviparous cockroaches belong to one family, the Blaberidae (McKittrick, 1964) and the arrangement of their male genital phallomeres are similar with the hook $\left(\mathrm{R}_{2}\right)$ always on the right side (Fig. IO). The Plectopterinae (Blattellidae) also have the hook on the right, but in the other 4 blattellid subfamilies (Anaplectinae, Blattellinae, Ectobiinae, and Nyctiborinae), the male genitalia are the mirror image of those of the Plectopterinae and Blaberidae, having the retractable hook on the left side (McKittrick, 1964). The hooked phallomere ( $\left.\mathrm{L}_{3}\right)$ of Parasphaeria linearis (Fig. 9) is on the left and the phallomere L2d clearly shows a close relationship to members of the Nyctiborinae, in which subfamily I place this species.

In this paper, I shall redescribe Parasphaeria ovata, and erect a new genus for Parasphaeria linearis, in part from specimens used by Brunner ( 1865 ) when he described the genus. I have examined the $\hat{o}$ and $\&$ types of Blatta ovata Blanchard, and Brunner was correct in his determination of his specimens of this species. Complete synonyms for these 2 species can be found in Princis (1964).

\section{Paramuzoa, n. gen.}

Type species: Blatta linearis Serville (present designation)

Paramuzoa appears to be close to Muzoa Hebard, having sym-

*Manuscript received by the editor October 2, 1973 

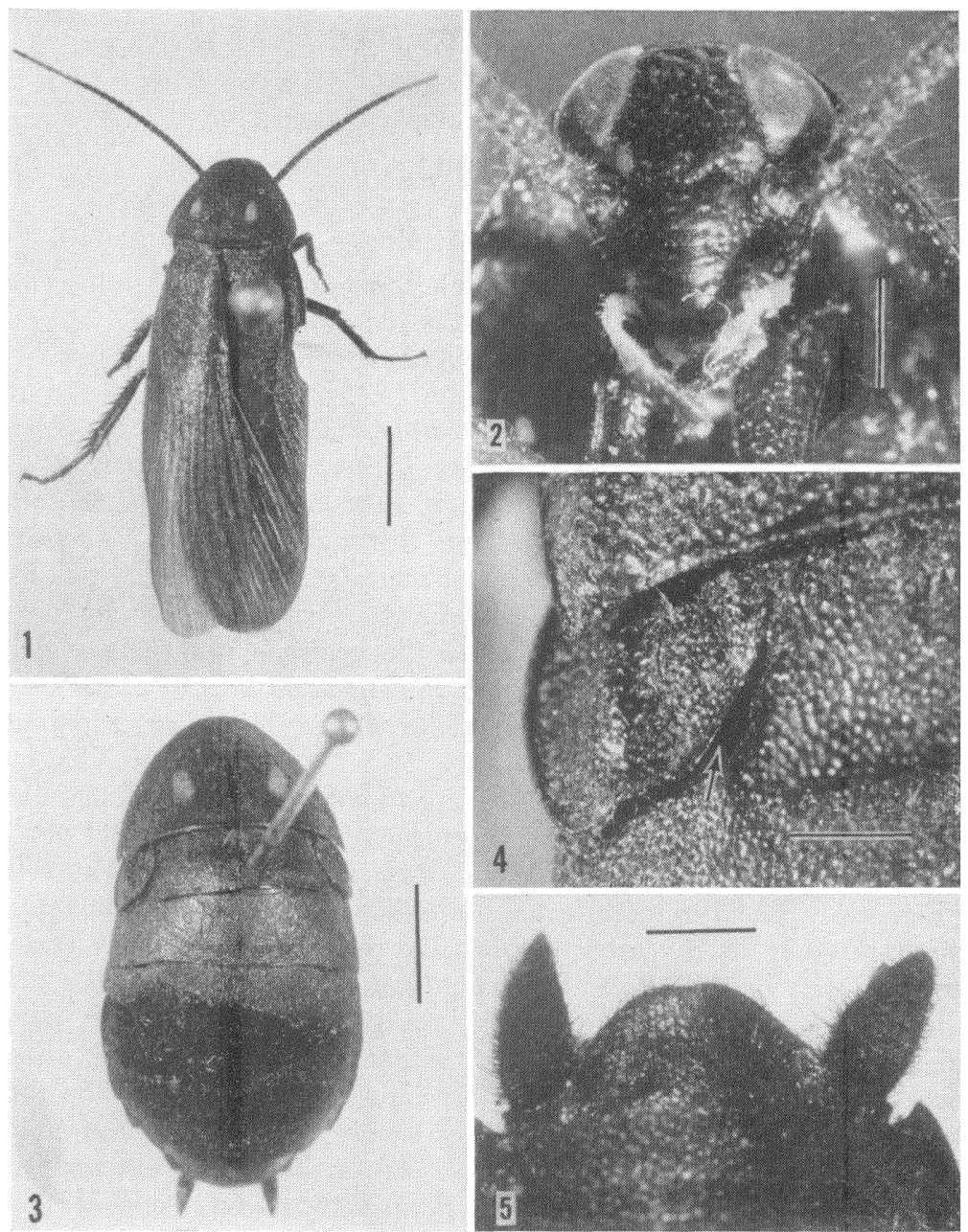

Figs. 1-5. Adults of Paramuzoa linearis. 1. Male (Brazil). 2. Head $\left(\sigma^{\pi}\right)$ (From specimen shown in Fig. 1). 3. Female (Brazil). 4. Left side of female mesonotum showing the deep, incomplete lateral incision (arrow) resulting in a tegmenlike lobe. 5. Supra-anal plate and cerci (dorsal) of 9 . (Figs. 4 and 5 from female shown in Fig. 3. (Both adults from Brunner's collection at the Natural History Museum, Vienna; scale: figs. $1,3=5 \mathrm{~mm}$, figs. $2,4-5=1 \mathrm{~mm}$ ). 
metrical tarsal claws; in other genera of Nyctiborinae symmetrical claws are found only in Megaloblatta (Hebard, I92I, p. I32). Although the shape of L2d (Fig. 9) of Paramuzoa differs from that of Muzoa madida Rehn, both have this phallomere tapering to a sharp point directed to the left. In addition to specific differences which distinguish it from Muzoa, the male of Paramuzoa has an asymmetrical subgenital plate and the right and left styles differ markedly in size (Fig. 8); in Muzoa the subgenital plate is symmetrical and the styles are equal. Femoral armament also differs between the 2 genera. The female of Paramuzoa is wingless and the mesonotum is modified laterally to form lobes which appear to be movable tegmina (Fig. 3) but anteriorly are actually part of the mesonotum (Fig. 4). The females of Muzoa are fully winged.

\section{Paramuzoa linearis (Serville), n. comb.}

(Figs. I-9)

Syn. Blatta linearis Serv. (Serville, r831, Ann. Sci. nat. 22, p. $4 \mathrm{I}, \sigma^{\circ}$ )

Parasphaeria linearis (Serv.) (Brunner, I865; 3I4, $\sigma^{\top}$ and o)

$\sigma^{\top}$ (Figs. I, 6). - Violaceous black. Head black, except for a broad testaceous band above the labrum; surface pitted (Fig. 2). Last segment of labial and maxillary palps black, the others testaceous. Eyes wide apart, the interocular space larger than the width of one eye. Antennae black, except for about 6 distal yellowish segments terminating in several apical black segments (Fig. 6). Pronotum densely pitted, piliferous, anterior and posterior margins rounded, widest at posterior border, metallic blackish except for 2 smooth orange spots below the middle. Tegmina piliferous, the anterior portion distinctly pitted. Wings infuscated (Fig. 6). Legs black. Ventral femoral margins: Front femur; anterior margin lined with small piliform setae, those on the distal half closer together; distal spine present, genicular spine absent. Mid femur: piliform spines on both margins; hind margin with I large spine, absent on anterior margin, distal spines on both margins, the anterior larger than the one on the posterior margin, genicular spine present. Hind femur: anterior margin with piliform spines only, plus a distal spine; posterior margin with piliform spines and one large spine, distal spine absent, genicular spine present. Tarsi with large pulvilli on all segments; tarsal claws simple, equal, with large arolia. Supraanal plate with sides straight, hind margin unevenly convex; cerci about 4 times as long as wide, piliferous (Fig. 7). Subgenital plate 


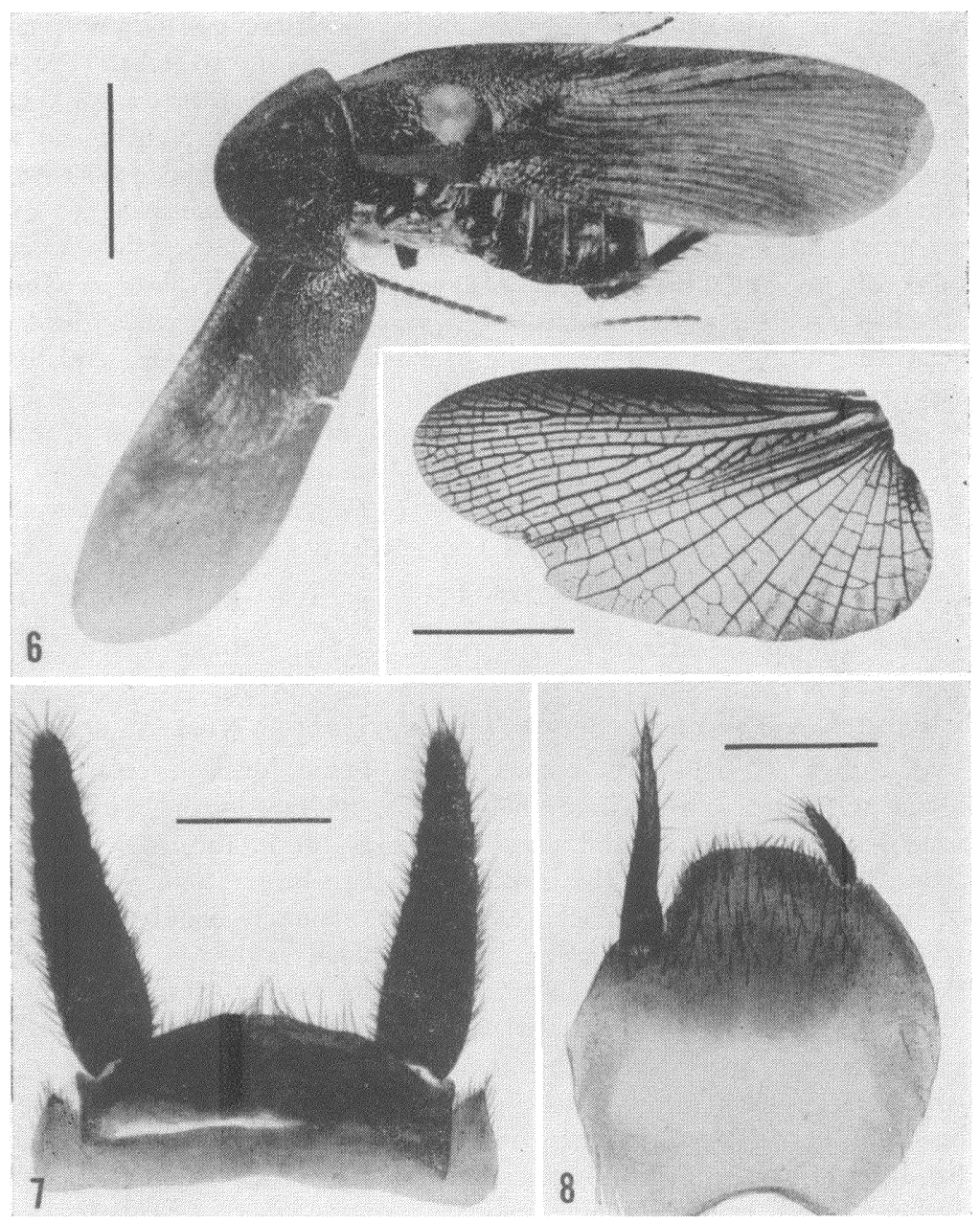

Figs. 6-8. Paramuzoa linearis. 6. Adult $\hat{\delta}$ and left wing (São Paulo, Cipo, Brazil, 25-XI-1967, leg. V. N. Alin, U.S. National Museum; det. Gurney). 7. Supra-anal plate and cerci (dorsal). 8. Subgenital plate and styles (ventral). (Figs. 7 and $8 \mathrm{KOH}$ preparations from specimen shown in Fig. 6 ; scale: fig. $6=5 \mathrm{~mm}$, figs. $7-8=1 \mathrm{~mm}$ ). 
asymmetrical, the hind margin rounded; styles slender, the left about 2.5x longer than the right (Fig. 8). Genitalia shown in figure 9; $\mathrm{R}_{2}$ with a subapical incision; L2d touching, but not attached to $\mathrm{L}_{2}$ $\mathrm{vm}$, tapering to a sharp point directed to the left.

Measurements (mm.) of Brunner's specimen (Brazil) as follows: width and length of pronotum - 5.4 and 4.2 respectively; length and width of tegmen $\mathrm{I} 7$ and 4 respectively; body length 15 .

o (Fig. 3) - Larger than and differs from male as follows: Head hidden under anterior margin of pronotum. Pronotum with hind margin slightly convex, the lateral corners curved backwards. What appear to be movable tegmina are actually a modification of the mesonotum which is deeply incised laterally forming a small lobe having a broad longitudinal convex swelling; anteriorly the mesonotum is entire and the mesad margin of the lobe continues as a groove in the mesonotal surface (Fig. 4) enhancing the impression of a freely moving tegmen (Fig. 3). Wings absent. Ventral hind margin of mid femur with 2 large spines. Tergites with fine recumbent hairs, their insertions giving a finely pitted appearance. Sternites somewhat similar to tergites. Supra-anal plate piliferous, the hind margin strongly rounded with a shallow mesad indentation; cerci flattened dorsally, convex ventrally, about twice as long as wide, extending well beyond the hind margin of the supra-anal plate (Fig. 5). Mid portion of subgenital plate weakly convex, laterally strongly curved dorsad, hind margin rounded, laterally undulate.

Measurements (mm.) of Brunner's specimen (Brazil) as follows: Width and length of pronotum 8 and 5.6 respectively; width and length of tegmen 2.5 and 2.8 respectively; length of body about I9 $\mathrm{mm}$.

\section{Parasphaeria ovata (Blanchard)}

(Figs. IO-19)

$\sigma^{*}$ (Figs. II, 14). - Head brown, exposed beyond anterior margin of pronotum; interocular space about $1.6 x$ width of an eye; interocellar space less than distance between eyes; labrum and clypeus testaceous; antennae brown, longer than body. Pronotum widest at about the middle, hind border convex, disk chestnut brown, impressed, resulting in an uneven surface; anterior and lateral borders testaceous. Tegmina very long, basally relatively narrow and expanding beyond, testaceous, nearly transparent; veins testaceous, prominent, especially on the basal half. Wings as long as tegmina, hyaline, veins testaceous. Front femur: basal half of ventro-anterior margin with 

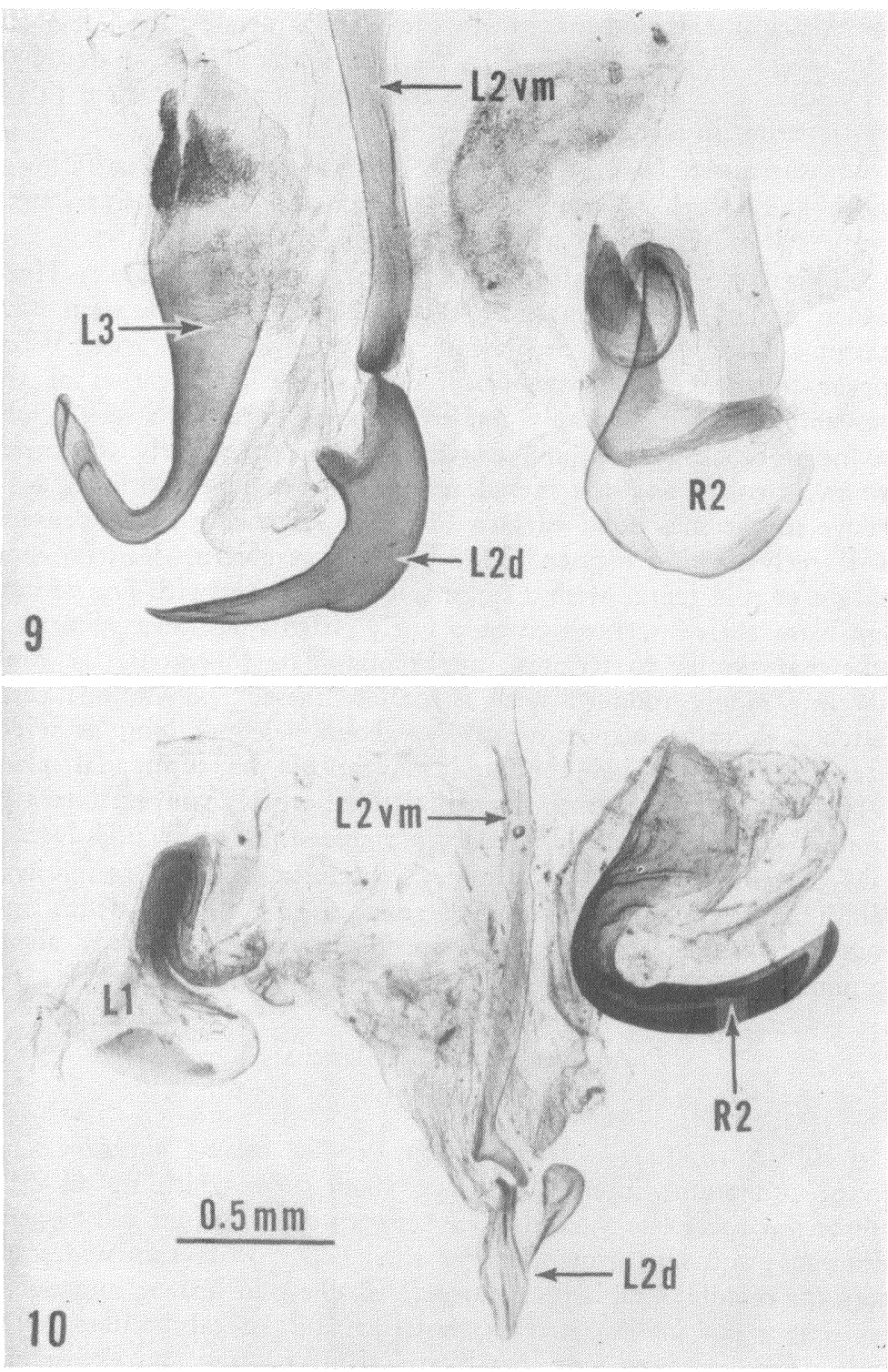

Figs. 9-10. Male genitalia (dorsal). 9. Paramuzoa linearis (From specimen shown in Fig. 6). 10. Parasphaeria ovata (From specimen shown in Fig. 14). Phallomeres numbered according to McKittrick (1964). (KOH preparations; the phallomeres have been separated somewhat, and flattened; Figs. 9 and 10 to same scale). 

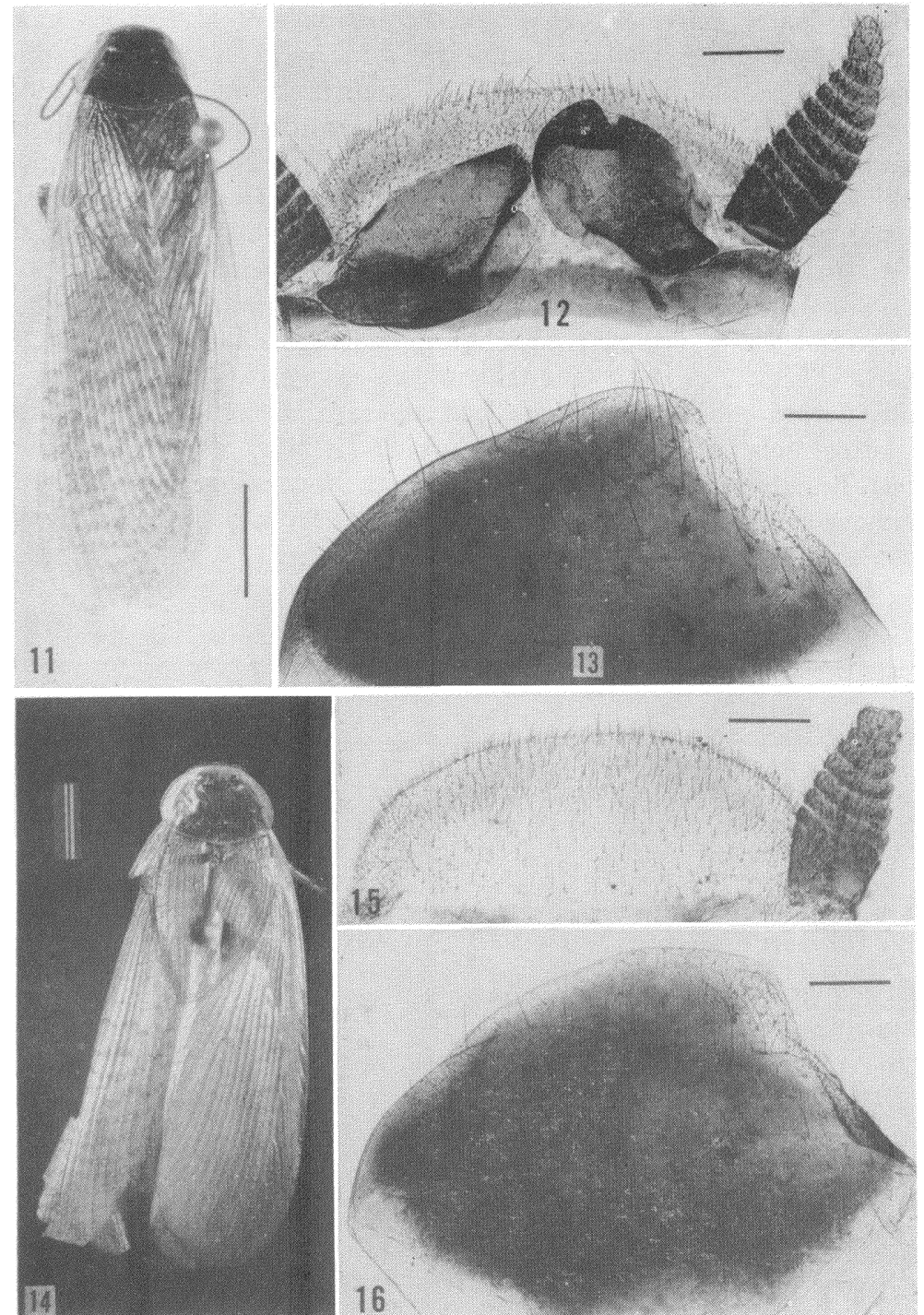

Figs. 11-16. Adult males of Parasphaeria ovata. 11. Chile (U.S. National Museum, det. Gurney). 12. Supra-anal plate, cerci, and paraprocts (ventral). 13. Subgenital plate (ventral). (Figs. 12-13 from $\hat{o}$ shown in Fig. 11). Chile (Brunner's specimen from the Natural History Museum, Vienna). 15. Supra-anal plate (dorsal). 16. Subgenital plate (ventral). (Figs. 15-16, from $\hat{o}$ shown in Fig. 14 ; scale: figs. $11,14=5 \mathrm{~mm}$, figs. $12-$ $13,15-16=0.5 \mathrm{~mm})$. 
widely spaced piliform spines followed by a row of smaller more closely spaced fine spines, small distal spine present, genicular spine absent. Mid and hind femora: ventro-anterior and posterior margins unarmed (except for some small piliform spines), distal spines absent, small genicular spines present. Tarsal claws simple, equal, arolia and pulvilli well developed. Abdomen testaceous, lacking tergal glands; hind margin of supra-anal plate rounded and piliferous; surface covered with small setae, more numerous on the posterior half (Fig. 15); right and left paraprocts bulbous (Fig. I2); subgenital plate asymmetrical, slightly indented on the right; styles absent (Figs. 13, I6). Genitalia shown in figure 10; $R 2$ on right side, with a subapical incision; L2d separated from L2vm and with a lateral lobe which is directed dorsad; $\mathrm{Lr}_{\mathrm{r}}$ with a deep upturned cleft, heavily sclerotized along the margins; lower lobe (below cleft) without setae (what appears to be setae are actually on a membrane which overlaps the lobe).

TABLE 1. Measurements (mm) of Parasphaeria ovata

\begin{tabular}{|c|c|c|c|c|c|}
\hline & & & & & \\
\hline & & leng & width & & ridth \\
\hline$\hat{o}$ & & & & & \\
\hline Chile, Type (Paris Museum) & 21 & 4.3 & 5.7 & 25.5 & - \\
\hline $\begin{array}{l}\text { Chile (Brunner's specimen; } \\
\text { Vienna Museum) } \\
\$\end{array}$ & 22 & 4.4 & 5.8 & 26 & - \\
\hline Chile, Type (Paris Museum) & 26 & 6.1 & 9 & 4.2 & 3.1 \\
\hline $\begin{array}{l}\text { Peru (Brunner's specimen; } \\
\text { Vienna Museum) }\end{array}$ & 28 & 6.1 & 8.3 & 4.1 & 2.9 \\
\hline $\begin{array}{l}\text { Ancud, Chiloé Island, Chile } \\
\text { (2-7 April 1920, Cornell Univ. } \\
\text { Exp.; Phila. Acad. Natural Sci. } \\
\text { det. Hebard) }\end{array}$ & 25 & 6.5 & 9.1 & 4.3 & 3.2 \\
\hline $\begin{array}{l}\text { Araucana, S. Chile (R. M. } \\
\text { Middleton, 1907-337; British } \\
\text { Museum; det. Hebard, 1928) }\end{array}$ & 23 & 5.6 & 8.3 & 4.2 & 2.9 \\
\hline $\begin{array}{l}\text { Unlabeled specimen in British } \\
\text { Museum }\end{array}$ & 28 & 6.5 & 10.4 & 4.5 & 3.4 \\
\hline $\begin{array}{l}\text { "Brunner (1865) lists Chile as } \\
\text { label indicated it was from Per } \\
\text { limited in distribution to the sou } \\
\text { determination of Shelford's reco } \\
\text { nymphs, apparently of this specie } \\
\text { collection data: 1) L. Nahuel H } \\
\text { tina, Terr. Rio Negro, F. and }\end{array}$ & $\begin{array}{l}\text { as the lo } \\
\text { eru. Rehr } \\
\text { outhern h } \\
\text { cord of } \\
\text { cies, at th } \\
\text { Huapi, } \mathrm{T} \\
\text { M. Edv }\end{array}$ & $\begin{array}{l}933 \text { ) } \\
\text { of C } \\
\text { ale } \\
\text { itish } \\
\text { to Bl }\end{array}$ & $\begin{array}{l}\text { his } \\
\text { elieve } \\
\text { le and } \\
\text { om Ec } \\
\text { Iuseun } \\
\text { t 2-3. } \\
\text { Casa }\end{array}$ & $\begin{array}{l}\text { men, } \\
P . \\
\text { T }\end{array}$ & $\begin{array}{l}\text { At the } \\
\text { ta is } \\
\mathrm{d} \text { the } \\
\text { small } \\
\text { owing } \\
\text { rgen- }\end{array}$ \\
\hline
\end{tabular}




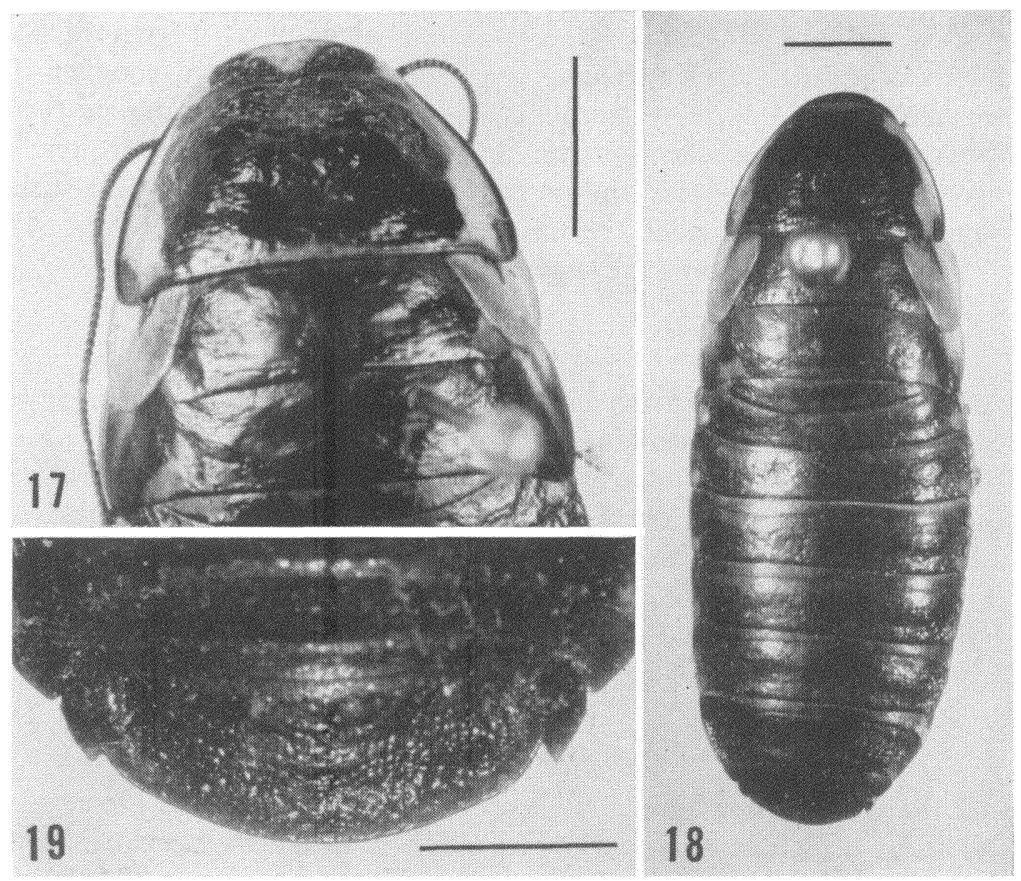

Figs. 17-19. Adult females of Parasphaeria ovata. 17. Thorax and part of abdomen (Chile, U.S. National Museum; det. Gurney). 18. Peru (Brunner's specimen from the Natural History Museum, Vienna). 19. Terminal segments of female shown in Fig. 18. (scale: fig. $17=4 \mathrm{~mm}$, fig. $18=$ $5 \mathrm{~mm}, 19=2 \mathrm{~mm}$ ).

Male measurements are shown in Table $\mathrm{I}$.

우 (Figs. I7, I8). - Dark brown, metallic. Head exposed beyond front margin of pronotum, largely black, shiny, with widely spaced fine dot-like impressions; labrum, lower border of clypeus, and area above and below antennal insertions testaceous; lower part of frons weakly wrinkled; antennae black, not quite length of body; last segments of maxillary palps darker than the others. Pronotum convex, widest at posterior border; uneven testaceous band borders the pronotum to the hind margin; posterior angles black. Tegmen lobiform, lateral, reaching slightly beyond hind margin of mesonotum, testaceous except for a dark incomplete humeral stripe. Metanotum black with a testaceous spot at each of the 2 anterior angles and 2 other similar markings on the posterior border within the posterior 
angles. Legs stout, short, testaceous, margined with brown; armament as in $\sigma^{*}$. Abdomen convex, shiny black, slightly roughened; segments 2 to 7 with testaceous spots on the posterior angles, these spots decreasing in size from the anterior to the posterior tergites; a broad median testaceous band on sternites I-5, the remainder blackish; supra-anal plate rounded, entire, cerci small, triangular (Fig. 19).

Female measurements are shown in Table $\mathrm{I}$.

\section{SUMMARY}

The Brazilian cockroach originally described as Blatta linearis by Serville has been referred to the genus Parasphaeria by Brunner; it is not a member of this ovoviviparous genus (Blaberidae). P. linearis is oviparous with characters placing it in the subfamily Nyctiborinae (Blattellidae), and Paramuzoa n. gen. is erected for this species. The male genitalia of Parasphaeria ovata (Blanchard) indicate that it is a member of the Epilamprinae and is not close to Perisphaeria (Perisphaeriinae) as suggested by Brunner.

\section{AcKNowledgements}

I thank the following for the loan of specimens: Dr. M. Descamps, Museum of Natural History, Paris, for Blanchard's types of Parasphaeria ovata; Dr. A. Kaltenbach, Natural History Museum, Vienna, for Brunner's specimens of $P$. ovata and $P$. linearis; Dr. Ashley Gurney, U. S. National Museum, Dr. David Rentz, Philadelphia Academy of Natural Sciences, and Dr. David R. Ragge, British Museum (Natural History), London, for additional specimens. I also thank Mr. Samuel Cohen for taking the photographs.

\section{REFERENCES}

BRUNNER VON WATTENWYL, C.

1865. Nouveau système des Blattaires. Vienna, $426 \mathrm{pp}$.

Hebard, M.

1921. Studies in the Dermaptera and Orthoptera of Colombia. Second paper. Trans. Am. Entomol. Soc. 47: 107-169.

KIRBY, W. F.

1904. A synonymic catalogue of Orthoptera. 1: 61-205. London.

McKitTrick, F. A.

1964. Evolutionary studies of cockroaches. Cornell Univ. Agric. Exp.

Princis, K. St. Mem. 389, 197 pp.

1964. Orthopterorum Catalogus. Pars 6: 174-281. 's - Gravenhage.

REHN, J. A. G.

1933. On the Dermaptera and Orthoptera of Chile. Trans. Am. Entomol. Soc. 59 : 159-190. 

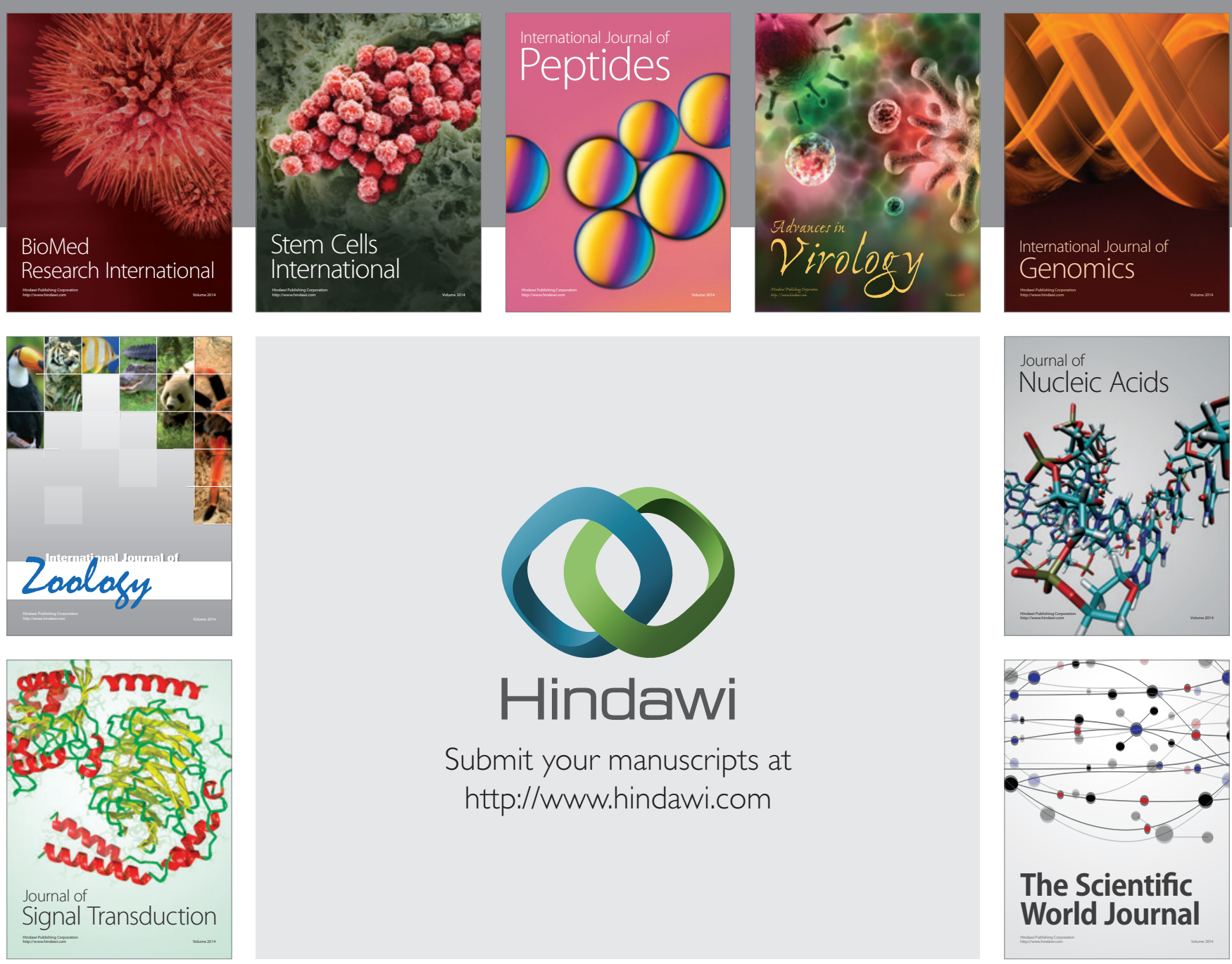

Submit your manuscripts at

http://www.hindawi.com
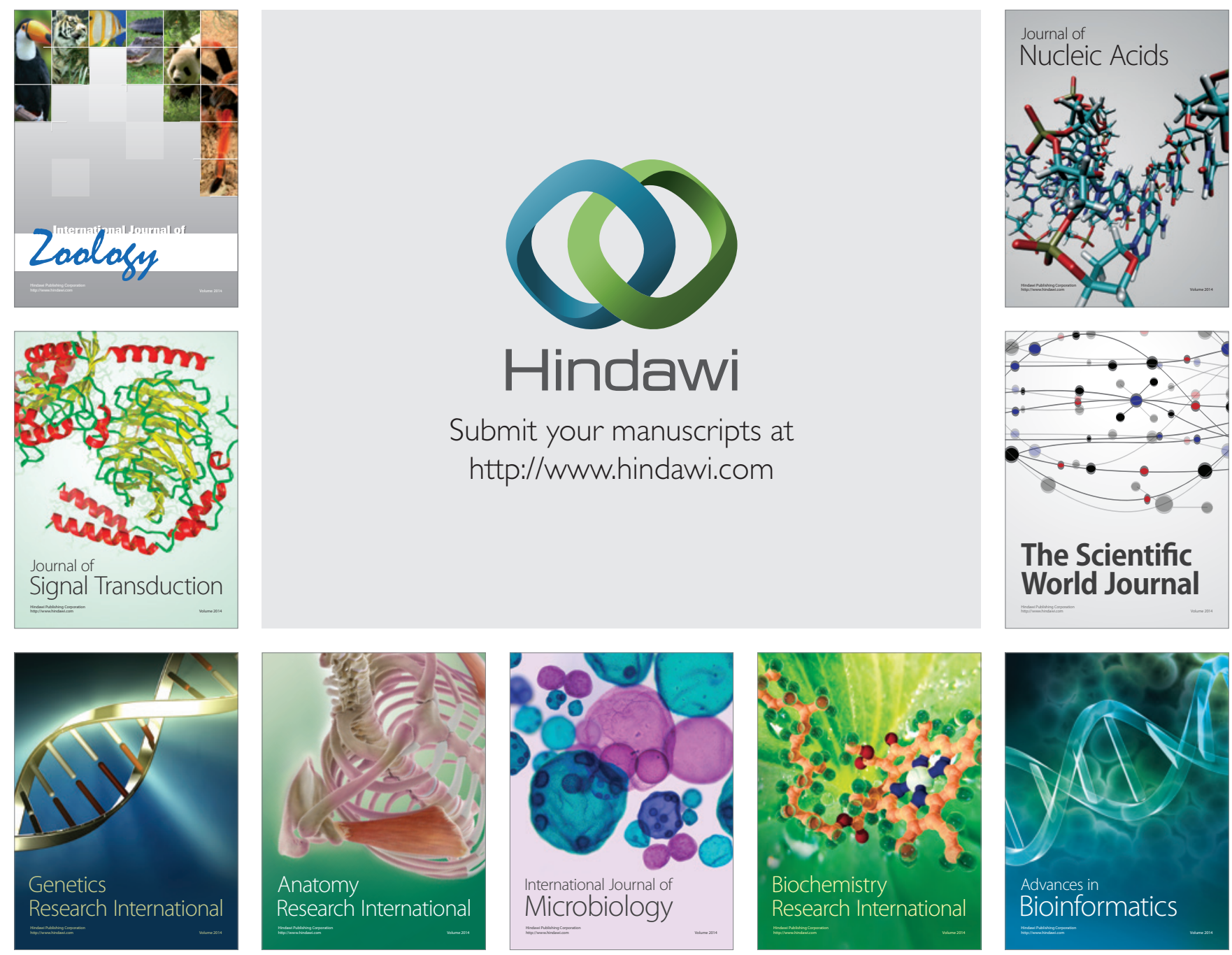

The Scientific World Journal
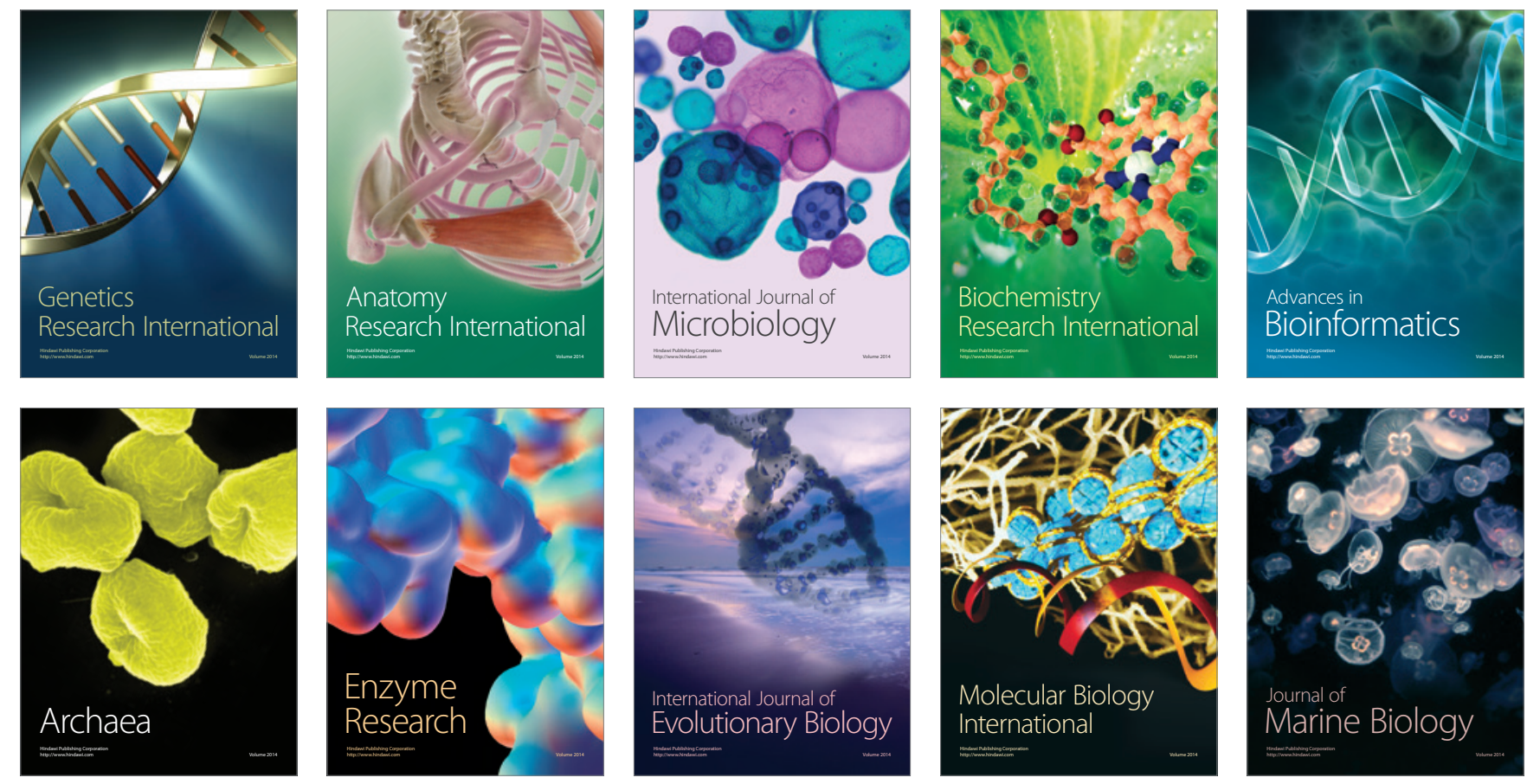